\title{
Analisis Potensi Pulau Maratua Sebagai Destinasi Pariwisata Andalan Indonesia Timur
}

Indonesian Journal of Tourism and Leisure, 2021
Vol. 02 (1), 14-25
(c) The Journal, 2021
DOI: $10.36256 /$ ijtl.v2i1.124
https: / / journal.lasigo.org/index.php/IJTL
Article History
Received: January $29^{\text {th }}, 2021$
Revised: March $7^{\text {h }}, 2021$
Accepted: March $22^{\text {th }}, 2021$

\section{Iya' Setyasih}

Pendidikan Geografi, Universitas Mulawarman, Kalimantan Timur, Indonesia iyasetyssih@mail.com

\section{Maya Wandyana Helmy}

Pendidikan Geografi, Universitas Mulawarman, Kalimantan Timur, Indonesia wandyana@yahoo.com

\begin{abstract}
Maratua Island is a part of the National Tourism Strategic Area (KSPN), namely Derawan-Sangalaki, in Berau Regency. This study aims to analyze the potential that can be developed on Maratua Island as a tourism destination in eastern Indonesia. This research is a quantitative descriptive study. To identify the tourism potential that can be developed on Maratua Island, use a modified guide to the Analysis of the Operational Areas for Natural Tourism Objects and Attractions (ADO-ODTWA). Maratua Island has the potential as a natural tourism destination in the form of flora and fauna, coral reefs, mangrove forests, lakes, and natural panoramas that are worthy of being developed. Based on the analysis of the factors of attractiveness, accessibility, socio-economic conditions, accommodation, sapras, and water availability, the index is $84 \%$ or feasible to develop. Maratua Island is in an advantageous condition because it has its own airport and port. For this reason, the Berau Regency Government needs to promote the potential that exists in Maratua Island, a five-year work plan is made for sustainable tourism development, involves the community in tourism management and cooperates with parties so that the development of Maratua Island tourism potential can be better.
\end{abstract}

Keywords: Nature Tourism Potency; Tourism; Maratua Island

\begin{abstract}
ABSTRAK
Pulau Maratua merupakan salah satu bagian dari Kawasan Strategis Pariwisata Nasional (KSPN) yaitu Derawan-Sangalaki di Kabupaten Berau. Penelitian ini bertujuan untuk menganalisis potensi yang bisa dikembangkan di Pulau Maratua sebagai destinasi pariwisata di wilayah Indonesia timur. Penelitian ini merupakan penelitian deskriptif kuantitatif. Untuk mengidentifikasi potensi pariwisata yang bisa dikembangkan di Pulau Maratua, menggunakan panduan Analisis Daerah Operasi Obyek dan Daya Tarik Wisata Alam (ADO-ODTWA) yang dimodifikasi. Pulau Maratua memiliki potensi sebagai destinasi pariwisata alam berupa flora dan fauna, terumbu karang, hutan mangrove, danau, dan panorama alam yang layak untuk dikembangkan. Berdasarkan analisis faktor daya tarik, aksesibilitas, kondisi sosial ekonomi, akomodasi, sapras, dan ketersediaan air diperoleh indeks $84 \%$ atau layak untuk dikembangkan. Pulau Maratua berada dalam kondisi yang menguntungkan karena memiliki bandara dan
\end{abstract}


pelabuhan sendiri. Untuk itu Pemkab Berau perlu mempromosikan potensi yang ada di Pulau Maratua, dibuat perencanaan kerja lima tahun untuk pengembangan wisata berkelanjutan, melibatkan masyarakat dalam pengelolaan wisata dan menjalin kerjasama dengan para pihak sehingga pengembangan potensi wisata Pulau Maratua dapat menjadi lebih baik.

Kata Kunci: Potensi Wista Alam; Pariwisata; Pulau Maratua.

\section{Pendahuluan}

Indonesia merupakan salah satu negara terluas di dunia dengan luas $5.193 .250 \mathrm{~km}$, yang meliputi luas daratan $1.919 .440 \mathrm{~km}^{2}$ dan lautan $3.273 .810 \mathrm{~km}^{2}$. Indonesia juga memiliki garis pantai terpanjang kedua di dunia, yaitu sepanjang $108.000 \mathrm{~km}$ serta mempunyai 17.504 pulau besar dan kecil (Susmoro, 2019) yang memiliki beragam kekayaan alam dan potensi untuk pariwisata. Pulau Maratua merupakan salah satu pulau yang memiliki potensi pariwisata, yang berupa keindahan alam, terutama keindahan bawah laut. Pulau Maratua terletak di Kabupaten Berau, yang merupakan salah satu dari 88 Kawasan Strategis Pariwisata Nasional (KSPN) yaitu Derawan-Sangalaki (Kemenpar, 2011). Di wilayah ini terdapat 125 daya tarik wisata alam, 27 daya tarik wisata budaya, dan 21 daya tarik wisata buatan. Daya tarik wisata tersebut merupakan potensi wisata yang harus dikembangkan.

Adapun konsep wisata Kabupaten Berau, khususnya pariwisata di Pulau Derawan - Maratua - Sangalaki dan sekitarnya diintegrasikan menjadi satu kawasan pariwisata yang menonjolkan keasrian dan kelestarian alam bahari. Dimana pengembangan pariwisata diarahkan pada pelibatan masyarakat lokal sebagai penerima manfaat ekonomi langsung dan turut serta bertanggungjawab atas kelangsungan potensi wisata. Pengembangan kepariwisataan diharapkan dapat dimanfaatkan secara arif dan berkelanjutan yang ditangani dan didukung oleh SDM yang profesional serta dapat mendorong kegiatan ekonomi yang terkait dengan pengembangan budaya serta daerah tujuan wisata di Kabupaten Berau.

Kabupaten Berau dikenal sebagai daerah wisata alam bawah laut, tidak hanya oleh wisatawan domestik tetapi juga wisatawan mancanegara. Tempat wisata yang menjadi daya tarik wisatawan adalah terutama Pulau Derawan, Pulau Maratua dan gugusan-gugusan pulau kecil di sekitarnya (Pemkab Berau, 2018). Potensi bahari dimaksud cenderung merupakan jenis wisata minat khusus seperti gua, spot diving dengan keanekaragaman biota laut di dalamnya diantaranya Jetty Dive, Turtle Traffic, Mid Reef, Eel Garden, Hanging Garden, Cabbage Garden, dan The Channel dan memiliki terumbu karang bertipe fringing reef, danau, pantai dan hutan khas pulau atoll (Pemkab Berau, 2018). Berdasarkan rencana pola ruang di Pulau Maratua terdiri dari 7 zona pemanfaatan ruang dengan 9 sub zona yang disusun pada laut dengan kedalaman 0-4000 mdpl. Di Pulau Maratua telah terdapat 4 objek wisata bahari yang berada sesuai dengan pola ruangnya, yaitu pada sub zona wisata. Objek wisata bahari tersebut terdiri dari bangunan resort dan jetty, dengan luas bangunan paling besar adalah $6068 \mathrm{~m}^{2}$ dan dibangun di atas laut yang memiliki kedalaman 0 sampai $5 \mathrm{~m}$ di bawah permukaan air laut (Sidqi, Suharyanto, Astuti, \& Ardarini, 2019).

Wisata bahari di Pulau Maratua sangat potensial untuk dikembangkan, terutama untuk jenis wisata dengan minat khusus dan terbatas karena keterbatasan sumber daya. Sesuai dengan tujuan pembangunan berkelanjutan, menurut Sutamihardja (2004) mencakup upaya untuk mewujudkan safeguarding atau pengamanan terhadap kelestarian sumber daya alam dan lingkungan hidup yang ada dan pencegahan terjadi gangguan ekosistem dalam rangka menjamin kualitas kehidupan yang tetap baik bagi generasi yang akan datang. Selain itu, untuk mempertahankan kesejahteraan rakyat (masyarakat) yang berkelanjutan baik masa kini maupun masa yang mendatang (inter temporal).

Pulau Maratua yang masih merupakan gugusan kepulauan Derawan-Sangalaki dan sekitarnya, selain potensi perikanan juga memiliki potensi pariwisata yang sangat menarik. 
Kunjungan wisata baik lokal maupun mancanegara terus meningkat dari tahun ke tahun (Pemkab Berau, 2018). Namun dengan keterbatasan sumber daya untuk masa jangka panjang dan kesiapan pengembangan pariwisata Pulau Maratua sebagai wisata andalan di wilayah timur khususnya Kaltim, maka perlu dikaji potensi wisata di Pulau Maratua.

Dalam mendukung pengembangan pariwisata yang diarahkan pada meningkatkan kunjungan wisatawan dan menjadikan destinasi berdaya saing internasional, perlu diupayakan memperbaiki aksesibilitas, melengkapi amenitas dan kerjasama antar stakeholder dan investor, serta peningkatan SDM di lingkup pemerintah, pengusaha maupun masyarakat (Badarab, Trihayuningtyas, \& M. Liga Suryadana, 2017). Sehingga perlu dilakukan analisis potensi wisata di KSPN Derawan - Sangalaki dan sekitarnya, khususnya di Pulau Maratua. Bahkan dengan adanya issu Kalimantan Timur sebagai Ibu Kota Negara akan memberikan peluang besar di masa mendatang untuk mengembangkan wisata di Pulau Maratua. Dalam hal ini dukungan antar semua pihak dan sektor terkait harus saling melengkapi.

\section{Tinjauan Pustaka}

Salah Pembangunan di bidang kepariwisataan merupakan salah satu terobosan untuk meningkatkan pendapatan daerah dan negara. Sebagai langkah awal dalam memilih dan menentukan suatu potensi obyek wisata pantas untuk dikembangkan atau mendapatkan prioritas untuk dikembangkan, sebelumnya perlu dilakukan strategi pengembangan obyek wisata. Kabupaten Berau memiliki beragam jenis obyek wisata dan daya tarik wisata seperti wisata alam, wisata budaya, wisata sejarah, dan wisata buatan. Namun obyek wisata tersebut masih belum terkelola secara baik. Agar pembangunan dan pengembangan potensi wisata, terutama wisata alam di Pulau Maratua berjalan efektif dan efisien, maka perlu dilakukan analisis potensi dengan menggunakan ADO-ODTWA untuk memberikan manfaat yang optimal (Departemen Kehutanan RI, 2003).

Selain analisis potensi obyek dan daya tarik wisata, diperlukan juga analisis terkait sarana dan prasarana penunjang, aksesibilitas, akomodasi, ketersediaan air bersih, dan kondisi social ekonomi warga. Prasarana dan sarana pariwisata adalah sumber daya yang mutlak dibutuhkan oleh wisatawan dalam perjalanannya di daerah tujuan wisata, seperti: jalan/jembatan, listrik, air, telekomunikasi, dan lain-lain (Suwantoro, 2004). Untuk meningkatkan pembangunan dan pengembangan wisata diperlukan juga SDA dan SDM sebagai daya tarik, agar dapat membenahi segi potensi atraksi dan keunikan wisata (Budiani et al., 2018). Analisis terhadap potensi wisata penting untuk dilakukan sebagai dasar dalam pembangunan dan pengembangannya, selain untuk mengetahui peluang dan ancamannya (Hendriawan \& Mulyanie, 2018). Pada destinasi wisata yang berupa pulau kecil seperti Pulau Maratua, pengembangan potensi wisata diperlukan agar kunjungan wisatawan dapat meningkat atau stabil sepanjang tahun dan memberikan manfaat kepada masyarakat (Martín, Fernández, Martín, \& de Dios Jiménez Aguilera, 2017), sebab pengembangan sektor pariwisata yang baik, akan meningkatkan kondisi sosial ekonomi masyarakat (Olu, Ben, \& Paul, 2018).

Penelitian ini dilakukan untuk menganalisis potensi dalam mengembangkan pariwisata Pulau Maratua dan kesiapan dalam menyambut wisatawan internasional. Penilaian dilakukan dengan menggunakan instrumen Analisis Daerah Operasi Obyek dan Daya Tarik Wisata Alam (ADOODTWA) melalui pengamatan baik itu sarana prasarana dan potensi, sehingga dapat menilai potensi dalam mewujudkan Pulau Maratua sebagai destinasi wisata andalan berbasis ekowisata berkelanjutan juga sebagai brand image Pulau Maratua dapat bersaing dengan pariwisata serupa lainnya. Analisis ini memberikan manfaat kepada masyarakat dan Pemda serta pengelola untuk meningkatkan infrastruktur dan promosi, sehingga wisatawan akan semakin meningkat dan tinggal lebih lama (Gedecho \& Guangul, 2017). Selain itu, dengan analisis ini dapat diketahui dan dikembangkan potensi yang merupakan kekhasan Pulau Maratua sehingga tetap dapat bersaing dengan destinasi pariwisata lainnya (Setyasih, Anwar, \& Anikmahardi, 2018). 


\section{Metode}

Penelitian ini menggunakan metode kuantitatif dengan analisis data penelitian menggunakan analisis deskriptif kuantitatif (Sugiyono, 2004). Peneliti menggambarkan kondisi potensi dan permasalahan pembangunan pariwisata di Pulau Maratua dan daya dukung lingkungannya dalam mengembangkan pariwisata Pulau Maratua yang berkelanjutan. Data angka hasil penilaian potensi wisata Pulau Maratua yang terdiri atas 6 item dijabarkan secara deskriptif untuk menjelaskan faktor-faktor yang sudah layak dan atau belum layak sebagai obyek wisata.

Penentuan jumlah responden dilakukan dengan menggunakan rumus Slovin (Setiawan, 2007). Pemilihan responden terdiri dari unsur pemerintah, seperti Balitbang Kabupaten Berau, Dinas Kebudayaan \& Pariwisata Kabupaten Berau, Dinas PUPR Kabupaten Berau, Dinas Perhubungan Kabupaten Berau, Dinas Pemberdayaan Masyarakat Kampung Kabupaten Berau, Camat Maratua, wakil Perbankan dan tokoh masyarakat dan LSM (tokoh Agama, Adat dan Pemuda serta organisasi setempat) serta pelaku/operator pariwisata (pemilik jasa travel, hotel, restoran, wisatawan).

Untuk teknik analisis data potensi wisata menggunakan Analisis Daerah Operasi Obyek dan Daya Tarik Wisata Alam (ADO-ODTWA). Analisis ini dipilih karena sesuai digunakan untuk penentuan skala prioritas dalam pembangunan dan pengembangan suatu obyek wisata alam (Departemen Kehutanan RI, 2003) seperti di Pulau Maratua. Berdasarkan hasil analisis ADOODTWA, dapat diketahui potensi yang dimiliki oleh Pulau Maratua sebagai destinasi pariwisata, dan sekaligus kekurangan yang harus dibenahi atau dilengkapi. Indikator atau kriteria dalam ADO-ODTWA meliputi: daya tarik, aksesibilitas, kondisi sosial ekonomi, akomodasi, sarana dan prasarana penunjang, dan ketersediaan air bersih.

\section{Hasil Penelitian}

\subsection{Gambaran Umum Lokasi Penelitian}

Wilayah penelitian berada di Kabupaten Berau yaitu Kecamatan Maratua. Kecamatan Maratua merupakan gugusan pulau atoll yang secara astronomis berada pada $2^{\circ} 15^{\prime} 12^{\prime \prime} \mathrm{LU}, 118^{\circ} 38^{\prime} 41^{\prime \prime}$ BT yang memiliki luas wilayah $4.119,54 \mathrm{Km}^{2}$. Berdasarkan posisi geografisnya, Kecamatan Maratua memiliki batas-batas wialayah sebagai berikut : Sebelah Utara: Laut Sulawesi, Sebelah Selatan: Selat Makassar, Sebelah Barat: Laut Sulawesi, dan Sebelah Timur: Kecamatan Pulau Derawan. Kecamatan Maratua terdiri dari 4 (empat) kampung, yaitu Maratua Teluk Harapan (merupakan Ibu Kota kecamatan), Maratua Payung-Payung, Maratua Bohe Silian dan Maratua Teluk Alulu.

Gambar 1. Peta Pulau Maratua

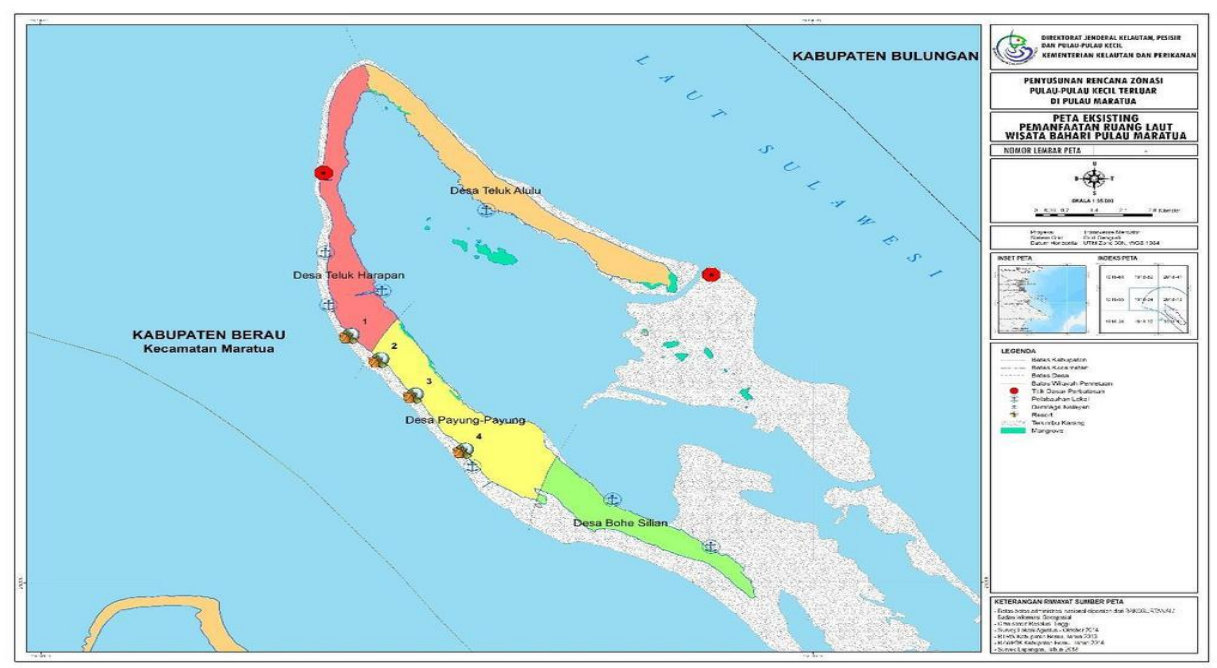

Sumber: Sidqi et al., (2019) 
Penduduk Kecamatan Maratua berjumlah 3.927 jiwa. Jika dilihat dari rasio jenis kelamin penduduk pria masih lebih banyak dibandingkan penduduk wanita yaitu 105,17. Sektor perikanan dan kelautan merupakan mata pencaharian utama penduduk di Pulau Maratua. Namun tahun 2018 jumlah nelayan budidaya laut semakin menurun hanya sebanyak $17 \mathrm{KK}$.

Potensi wisata di Pulau Maratua pada dasarnya adalah menonjolkan pada keunikan biota bawah laut yang berada di sekitar Pulau Maratua, Pulau Kakaban, Pulau Sangalaki dan Pulau Derawan yang kesemuanya merupakan bagian KSPN Derawan-Sangalaki. Adapun atraksi lainnya yang dapat dikembangkan adalah daya Tarik Kebudayaan Adat Bajau yang berada di Pulau Maratua dan Pulau Derawan. Pulau Maratua mempunyai diving dan snorkeling spot terbanyak di Kabupaten Berau, dan merupakan tempat berkumpulnya penyu bertelur dan feeding ground (area mencari makan bagi penyu) terbesar di Asia Tenggara. Selain itu, panorama sunrise dan sunset, rekreasi pantai dan hutan khas pulau atol serta danau juga menjadi daya tarik tersendiri di Pulau Maratua.

\subsection{Potensi Wisata Pulau Maratua}

\subsubsection{Daya Tarik}

Daya tarik merupakan alasan utama pengunjung untuk datang ke lokasi tersebut untuk melakukan kegiatan wisata. Pengkajian komponen daya tarik ini bertujuan untuk mengetahui gambaran bentuk-bentuk kegiatan rekreasi yang sesuai dengan daya tarik dan sumberdaya yang tersedia. Berdasarkan PKHA (Departemen Kehutanan RI, 2003) daya tarik merupakan modal utama yang memungkinkan datangnya pengunjung. Hasil penilaian terhadap daya tarik obyek wisata Pulau Maratua dapat dilihat pada tabel berikut.

Tabel 1. Penilaian Komponen Daya Tarik Pulau Maratua

\begin{tabular}{|c|c|c|c|c|c|}
\hline No & Unsur/Sub Unsur & Uraian & Bobot & Nilai & $\begin{array}{l}\text { Skor } \\
\text { Total }\end{array}$ \\
\hline 1 & $\begin{array}{l}\text { Keunikan sumber daya } \\
\text { alam }\end{array}$ & Flora dan fauna, keindahan laut & 6 & 30 & 180 \\
\hline 2 & $\begin{array}{l}\text { Banyaknya jenis sumber } \\
\text { daya yang menonjol }\end{array}$ & $\begin{array}{l}\text { Terumbu karang, pulau atol, hutan manggroe, padang } \\
\text { lamun, spot sunrise dan sunset. }\end{array}$ & 6 & 30 & 180 \\
\hline 3 & $\begin{array}{l}\text { Kegiatan alam yang } \\
\text { dapat dilakukan }\end{array}$ & $\begin{array}{l}\text { Diving, snorkling, menikmati panorama alam, olah raga, } \\
\text { melihat flora dan fauna }\end{array}$ & 6 & 30 & 180 \\
\hline 4 & $\begin{array}{l}\text { Kebersihan lokasi } \\
\text { obyek wisata }\end{array}$ & $\begin{array}{l}\text { Tidak ada vandalisme dan tersedia tempat sampah } \\
\text { (TPS) }\end{array}$ & 6 & 20 & 120 \\
\hline 5 & Keamanan kawasan & $\begin{array}{l}\text { Tidak ada arus pasang surut laut yang berbahaya, tidak } \\
\text { ada pencurian, tidak ada penyakit berbahaya }\end{array}$ & 6 & 30 & 180 \\
\hline \multirow[t]{2}{*}{6} & Kenyamanan & $\begin{array}{l}\text { Udara yang bersih dan sejuk, tidak ada lalu lintas yang } \\
\text { mengganggu, tersedianya sarana dan prasarana }\end{array}$ & 6 & 30 & 180 \\
\hline & & Skor Total Daya Tarik & & 170 & 1020 \\
\hline
\end{tabular}

Sumber: Hasil Olah Data Penelitian (2020)

Hasil penilaian terhadap komponen daya tarik di kawasan Pulau Maratua, dapat diketahui bahwa unsur/sub unsur kebersihan nilainya paling rendah, yaitu tidak tersedia TPA karena Pulau Maratua merupakan pulau karang dengan lapisan tanah yang tidak tebal dan tidak sesuai berdasarkan kriteria pembangunan TPA. Untuk itu akan dibangun pusat pengolahan sampah di Pulau Maratua, karena selama ini sampah yang ada dibawa ke daratan Pulau Kalimantan. Sedangkan keunikan daya tarik Pulau Maratua adalah keindahan alam, terutama panorama bawah laut yg berupa terumbu karang. Banyak destinasi pariwisata alam pulau-pulau kecil yang menonjolkan keindahan bawah laut (Kwon, Chung, Yoon, \& Kwon, 2017), namun belum dikembangkan secara optimal (Sidqi et al., 2019).

\subsubsection{Aksesibilitas}

Untuk aksesibilitas menuju Pulau Maratua berdasarkan kondisi jalan termasuk baik, sehingga mendukung aksesibilitas meskipun jarak dari ibu kota kabupaten cukup jauh yaitu lebih dari 100 
$\mathrm{km}$ dengan waktu tempuh lebih dari 3 jam serta tipe jalan aspal yang lebarnya 5 meter. Penilaian aksesibilitas dapat dilihat pada table 2 berikut ini:

Tabel 2. Penilaian Aksesibilitas Pulau Maratua

\begin{tabular}{clcccc}
\hline \multirow{2}{*}{ No } & \multirow{2}{*}{ Unsur/Sub Unsur } & \multirow{2}{*}{ Uraian } & Bobot & Nilai & $\begin{array}{c}\text { Skor } \\
\text { Total }\end{array}$ \\
\hline 1 & Kondisi jalan & Baik & 5 & 30 & 150 \\
2 & Jarak dari kota & $>100 \mathrm{~km}$ & 5 & 10 & 50 \\
3 & Tipe jalan & Jalan provinsi, aspal, lebar 5 m dan jalur laut & 5 & 30 & 150 \\
4 & Waktu tempuh dari kota & $>$ 3 jam & 5 & 20 & 100 \\
\hline \multicolumn{2}{r}{} & Skor Total Daya Tarik & & 80 & 450 \\
\hline
\end{tabular}

Sumber: Hasil Olah Data Penelitian (2020)

Selain kondisi jalan yang baik dan beraspal, di Pulau Maratua juga terdapat bandara dan pelabuhan yang mendukung aksesbilitas dari Tanjung Redep ke Pulau Maratua. Wisatawan dapat naik pesawat menuju Pulau Maratua dari Bandara Kalimarau Tanjung Redep atau Bandara Juwata Tarakan dengan maskapai Susy Air. Selain itu, wisatawan juga dapat naik speed boat dari Tanjung Redep menuju Pulau Maratua. Hal tersebut dapat memangkas waktu tempuh dari Ibu Kota kabupaten maupun provinsi menjadi kurang dari 3 jam. Faktor infrastruktur ini menjadi sangat penting dalam pembangunan dan pengembangan pariwisata (Gedecho \& Guangul, 2017).

Gambar 2. Bandara dan Pelabuhan Pulau Maratua

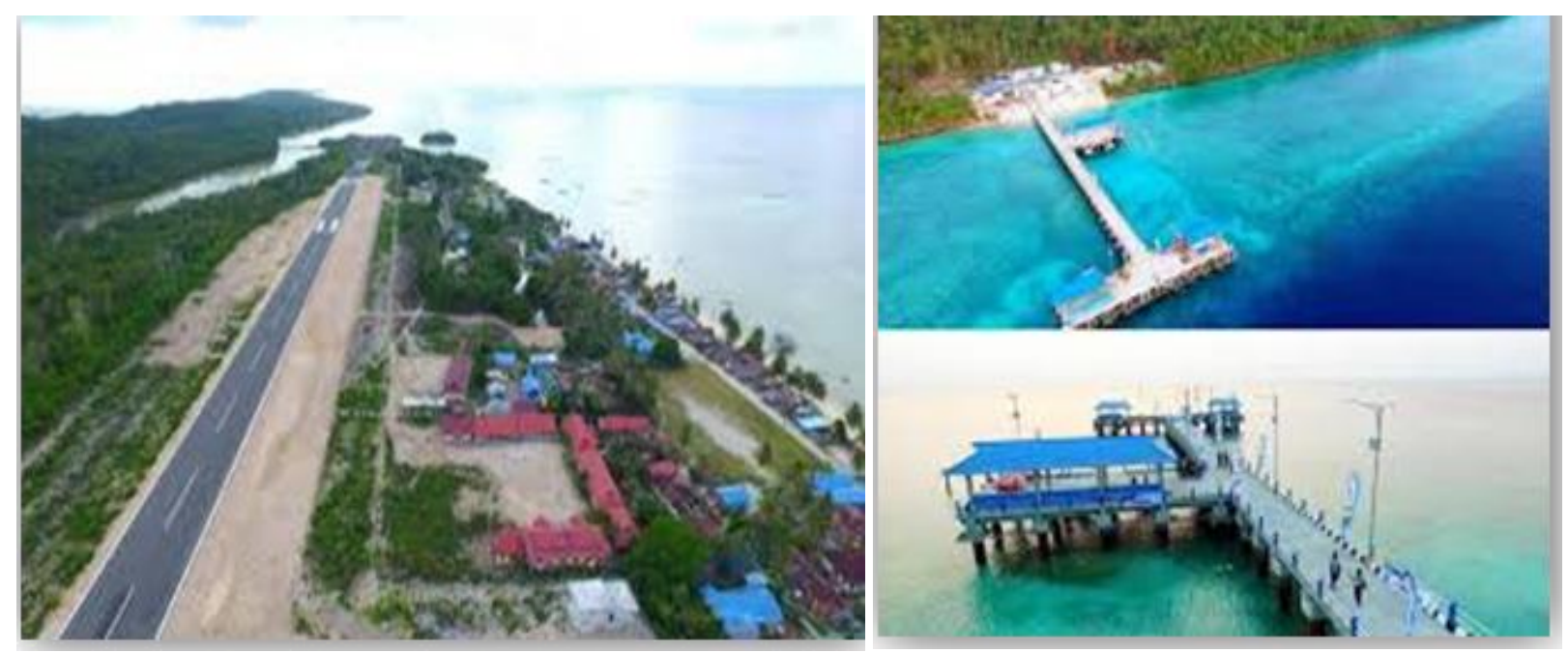

Sumber: kaltimprov.go.id dan batasnegeri.com

\subsubsection{Kondisi Sosial Ekonomi}

Penilaian kriteria kondisi sosial ekonomi dinilai dari wilayah Pulau Maratua. Penilaian kriteria kondisi sosial ekonomi pada obyek wisata alam Pulau Maratua dapat dilihat pada tabel 3.

Tabel 3. Penilaian Kondisi Sosial Ekonomi Pulau Maratua

\begin{tabular}{|c|c|c|c|c|c|}
\hline No & Unsur/Sub Unsur & Uraian & Bobot & Nilai & $\begin{array}{l}\text { Skor } \\
\text { Tota }\end{array}$ \\
\hline 1 & $\begin{array}{l}\text { Tata ruang wilayah } \\
\text { obyek }\end{array}$ & Belum ada & 5 & 20 & 100 \\
\hline 2 & Status lahan & Pemerintah dan masyarakat & 5 & 25 & 125 \\
\hline 3 & $\begin{array}{ll}\text { Mata } & \text { pecaharian } \\
\text { penduduk } & \end{array}$ & Nelayan, petani, pedagang, dan industri kecil & 5 & 25 & 125 \\
\hline \multirow[t]{2}{*}{4} & Pendidikan & Sebagaian besar lulus SMA ke atas & 5 & 30 & 150 \\
\hline & & Skor Total Daya Tarik & & 100 & 500 \\
\hline
\end{tabular}

Sumber: Hasil Olah Data Penelitian, 2020 
Berdasarkan tabel 3 hasil penilaian terhadap komponen kondisi sosial ekonomi di Pulau Maratua, menunjukkan bahwa semua unsur penataan tata ruang wilayah belum ada, namun sudah mulai dirintis oleh Pemda Berau. Status lahan di Pulau Maratua adalah milik negara dan masyarakat. Mata pencaharian penduduk sekitar obyek sebagai besar adalah nelayan, pedagang kecil, dan industri kecil dengan tingkat pendidikan sebagian besar adalah lulus SMA. Dengan dijadikannya Pulau Maratua sebagai destinasi pariwisata diharapkan akan memberikan manfaat bagi masyarakat (Martín et al., 2017) dan meningkatkan kondisi sosial ekonomi warga (Olu et al., 2018).

\subsubsection{Akomodasi}

Akomodasi merupakan salah satu faktor yang membuat pengunjung tertarik untuk melakukan sesuatu kunjungan wisata. Penilaian akomodasi wisata di Pulau Maratua dapat dilihat dalam tabel 4.

Tabel 4. Penilaian Akomodasi Pulau Maratua

\begin{tabular}{|c|c|c|c|c|c|}
\hline No & Unsur/Sub Unsur & Uraian & Bobot & Nilai & $\begin{array}{l}\text { Skor } \\
\text { Total }\end{array}$ \\
\hline 1 & Jumlah penginapan & $\begin{array}{l}\text { Resort } 4 \text { buah, penginapan } 10 \text { buah, dan home } \\
\text { stay } 55\end{array}$ & 3 & 25 & 75 \\
\hline \multirow[t]{2}{*}{2} & Jumlah kamar & 200 kamar & 3 & 25 & 75 \\
\hline & & Skor Total Daya Tarik & & 50 & 150 \\
\hline
\end{tabular}

Sumber: Hasil Olah Data Penelitian (2020)

Di Pulau Maratua pada saat puncak liburan akan terjadi over stay meskipun banyak tersedia resort, penginapan, dan homestay yang tersebar di sepanjang pantai maupun di dalam pulau. Hal ini karena banyak wisatawan baik dalam maupun luar negeri yang berlibur ke Pulau Maratua. Berdasarkan hal tersebut, penyediaan akomodasi terutama penginapan sangat penting untuk pengembangan potensi pariwisata, sehingga perlu pelibatan warga masyarakat dalam penyediaan akomodasi (Budiani et al., 2018).

\subsubsection{Sarana dan Prasarana Penunjang}

Sarana penunjang yang dinilai yaitu rumah makan, pusat perbelanjaan/pasar, bank. Prasarana penunjang yang dinilai meliputi kantor pos, jaringan telepon, puskesmas, jaringan listrik dan jaringan air minum. Hasil penilaian terhadap sarana dan prasarana penunjang di sekitar kawasan obyek wisata Pulau Maratua dapat dilihat pada tabel 5.

Tabel 5. Penilaian Sarana dan Prasarana Penunjang Pulau Maratua

\begin{tabular}{clcccc}
\hline No & $\begin{array}{c}\text { Unsur/Sub } \\
\text { Unsur }\end{array}$ & Uraian & \multirow{2}{*}{ Bobot } & Nilai & $\begin{array}{c}\text { Skor } \\
\text { Total }\end{array}$ \\
\hline 1 & Sarana & Kantor pos, telepon, puskesmas, jaringan listrik, PDAM & 3 & 50 & 150 \\
2 & Prasarana & Rumah makan, pusat perbelanjaan, bank & 3 & 30 & 90 \\
\hline \multicolumn{2}{r}{} & Skor Total Daya Tarik & 80 & 240 \\
\hline
\end{tabular}

Sumber: Hasil Olah Data Penelitian (2020)

Pelayanan kesehatan di Pulau Maratua melayani selama 24 jam dan ditangani oleh dokter. Untuk jaringan listrik tersedia PLTD. Sedangkan untuk prasarana tersedia 1 kantor cabang pembantu BPD Kaltimtara. Untuk rumah makan tersedia cukup banyak di Pulau Maratua, meskipun saat puncak liburan sering over capacity. Selain itu, di Pulau Maratua juga tersedia fasilitas ibadah, yaitu 5 buah masjid. Dari segi sarana dan prasarana di Pulau Maratua cukup tersedia dan dapat dikategorikan sebagai daerah yang cepat tumbuh (Kumala, Soelistyo, \& Nuraini, 2017), meskipun merupakan pulau kecil.

\subsubsection{Ketersediaan Air Bersih}

Air bersih merupakan faktor yang harus tersedia dalam pengembangan obyek baik untuk pengelolaan maupun pelayanan (Cole \& Browne, 2015). Pada pulau karang seperti Pulau 
Maratu, air merupakan salah satu permasalahan yang perlu mendapat perhatian. Hasil penilaian kriteria ketersediaan air bersih di Pulau Maratua dapat dilihat pada Tabel 6.

Tabel 6. Penilaian Ketersediaan Air Bersih Pulau Maratua

\begin{tabular}{|c|c|c|c|c|c|}
\hline No & Unsur/Sub Unsur & Uraian & Bobot & Nilai & $\begin{array}{l}\text { Skor } \\
\text { Total }\end{array}$ \\
\hline 1 & Volume & $\begin{array}{l}\text { Hanya terdapat } 1 \text { mata } \text { air dan } 1 \text { unit } \\
\text { penyulingan air laut }\end{array}$ & 6 & 25 & 150 \\
\hline 2 & Jarak sumber air bersih & $<1 \mathrm{~km}$ & 6 & 30 & 180 \\
\hline 3 & $\begin{array}{l}\text { Dapat tidaknya dialirkan } \\
\text { ke obyek wisata }\end{array}$ & Sebagian besar dapat teraliri air bersih & 6 & 25 & 150 \\
\hline 4 & Kelayakan konsumsi & Layak & 6 & 25 & 150 \\
\hline \multicolumn{3}{|c|}{ Skor Total Daya Tarik } & & 105 & 630 \\
\hline
\end{tabular}

Sumber: Hasil Olah Data Penelitian (2020)

Dari segi ketersediaan air bersih yang hanya terdapat 1 mata air dan 1 unit penyulingan air laut, sehingga tidak semua rumah penduduk terjangkau aliran air bersih. Penduduk kebanyakan memanfaatkan air hujan untuk memenuhi kebutuhan MCK. Berdasarkan analisis 6 (enam) kriteria ADO-ODTWA Pulau Maratua, maka hasilnya adalah sebagai berikut:

Tabel 7. Hasil Penilaian Obyek dan Daya Tarik Pulau Maratua

\begin{tabular}{clcccccc}
\hline No & Kriteria & Bobot & Nilai & Skor & Skor Max & Indeks & Ket \\
\hline 1 & Daya tarik & 6 & 170 & 1020 & 1080 & $94 \%$ & Layak \\
2 & Aksesibilitas & 5 & 80 & 450 & 600 & $75 \%$ & Layak \\
3 & Kondisi sosial ekonomi & 5 & 100 & 500 & 600 & $83 \%$ & Layak \\
4 & Akomodasi & 3 & 50 & 150 & 180 & $83 \%$ & Layak \\
5 & Sarana dan prasarana penunjang & 3 & 80 & 240 & 300 & $80 \%$ & Layak \\
6 & Ketersediaan air bersih & 6 & 105 & 630 & 720 & $87 \%$ & Layak \\
\hline \multicolumn{3}{c}{ Tingkat Kelayakan } \\
\hline \multicolumn{3}{c}{ Sumber: Hasil Olah Data Penelitian (2020) } & & & Layak \\
\hline
\end{tabular}

\section{Diskusi}

Berdasarkan hasil penilaian obyek dan daya tarik wisata, Pulau Maratua layak dikembangkan sebagai obyek wisata unggulan di Kabupaten Berau, terutama di wilayah Indonesia Timur. Dalam mendukung pengembangan pariwisata yang diarahkan pada meningkatkan kunjungan wisatawan dan menjadikan destinasi berdaya saing internasional, perlu diupayakan memperbaiki aksesibilitas, melengkapi amenitas dan kerjasama antar stakeholder dan investor, serta peningkatan SDM di lingkup pemerintah, pengusaha maupun masyarakat (Badarab et al., 2017). Hal tersebut terutama karena kompetensi penduduk Pulau Maratua di bidang pariwisata masih kurang, seperti keberadaan instruktur diving. Pengembangan pariwisata di Pulau Maratua yang merupakan bagian dari KSPN Derawan-Sangalaki dan sekitarnya, perlu ditingkatkan faktor pendukungnya.

Potensi yang dimiliki Pulau Maratua sebagai destinasi wisata unggulan di Indonesia Timur antara lain keindahan bawah laut, panorama alam, kekayaan flora dan fauna, atraksi adat, dan wisata buatan lainnya. Hal ini sejalan dengan pendapat (Yoeti, 2002) bahwa daya tarik wisata meliputi: (a) daya tarik alam: lanskap, pemandangan laut, pantai, iklim dan fitur geografis lainnya. (b) daya tarik budaya: sejarah dan cerita rakyat, agama, seni dan acara khusus. (c) atraksi sosial: cara hidup, populasi penduduk, bahasa, kesempatan untuk pertemuan sosial. (d) daya tarik buatan: bangunan bersejarah dan arsitektur modern, monumen, taman, kebun, marina, dll. Daya tarik alam yang dimiliki oleh Pulau Maratua tersebut memiliki keunikan dan kekhasan tersendiri yang berbeda dengan daerah lainnya, sehingga akan mampu bersaing dengan destinasi pariwisata sejenis. Daya tarik wisata di Pulau Maratua memiliki kesamaan dengan destinasi pariwisata di Pulau Jeju Korea selatan yang menitik beratkan pada atraksi bahari (Kwon et al., 2017). Namun demikian, antara Pulau Maratua dan Pulau Jeju memiliki perbedaan 
dan kekhasan, sehingga seperti yang dikemukakan Setyasih et al., (2018) bahwa destinasi wisata akan tetap bertahan dan terus berkembang karena memiliki keunikan dan kekhasan tersendiri.

Untuk lebih mengembangkan potensi tersebut, maka perlu didukung dengan kebijakankebijakan dari pemerintah, termasuk penyediaan infrastruktur yang memadahi dan baik (Suwantoro, 2004). Menurut Sidqi et al. (2019) Pulau Maratua merupakan satu dari 111 pulau kecil terluar (Indonesia, 2017) yang saat ini telah memiliki rencana zonasi pemanfaatan ruang laut. Pengelolaan wilayah pesisir dan pulau-pulau terkecil adalah suatu pengkoordinasian perencanaan, pemanfaatan, pengawasan, dan pengendalian sumber daya pesisir dan pulau-pulau kecil yang dilakukan oleh pihak pemerintah untuk meningkatkan kesejahteraan rakyat. Untuk itu perlu kebijakan pemerintah berupa RTRW pengembangan pariwisata Pulau Maratua. Dalam implementasi dari kebijakan yang akan diterapkan ada 4 (empat) faktor penyebab keberhasilan atau kegagalan yang tergantung pada faktor komunikasi, sumber daya, disposisi dan struktur birokrasi yang akan mempengaruhi keberhasilan dalam implementasi pengembangan pariwisata (Nugroho, 2018). Oleh karenanya perencanaan yang tepat dan terhadap kebutuhan faktor-faktor tersebut akan mempengaruhi percepatan pengembangan destinasi pariwisata baru di Indonesia Timur khususnya Pulau Maratua. Sama halnya dengan Provinsi Jawa Timur dalam mengembangkan sektor pariwisatanya, dimana tingkat kecepatan pertumbuhan dan kemajuan menjadi salah satu tolok ukurannya (Kumala et al., 2017), maka Pemkab Berau perlu meningkatkan pertumbuhan dan kemajuan yang ada di Pulau Maratua.

Untuk mencapai kemajuan pariwisata di Pulau Maratua diperlukan inovasi dan Pemda mengembangkan perannya dalam mengajak pihak swasta maupun masyarakat dalam mengembangkan obyek wisata (Kristin \& Salam, 2016). Untuk itu, pemerintah bersama masyarakat Pulau Maratua perlu bersinergi menciptakan inovasi-inovasi yang mendorong pertumbuhan wisata di Pulau Maratua. Termasuk peran stakeholder yang pada akhirnya akan meningkatkan tata kelola guna mempercepat proses pengembangan atraksi, aksesibilitas dan amenitas dalam satu kesatuan di destinasi pariwisata Pulau Maratua sebagai produk pariwisata (Middleton, 2001). Pemerintah daerah Kabupaten Berau juga perlu mengimplementasikan kebijakan terkait kebutuhan fasilitas pendukung wisata di Pulau Maratua. Peningkatan aksesibilitas dan sarana prasarana pariwisata terutama akses transportasi laut mutlak diperlukan sebagai tujuan wisata bahari kepulauan. Selain itu, juga perlu membangun kesadaran masyarakat dalam partisipasi untuk mengembangkan pariwisata bahari (Baskoro, 2018).

Pengembangan sektor pariwisata yang berlatar belakang alam pada pulau kecil seperti di Pulau Maratua, lebih menekankan produk dan kegiatan yang tidak terlepas dari daya tarik lingkungan. Kondisi yang ada di Pulau Maratua terdapat 4 objek wisata bahari berupa resort/penginapan wisata yang kebanyakan terdapat di Desa Payung-Payung. Resort paling besar memiliki luas $6068 \mathrm{~m}^{2}$ dan paling kecil memiliki luas $1066 \mathrm{~m}^{2}$ (Sidqi et al., 2019). Untuk itu pengembangan pariwisata juga perlu diarahkan pada kegiatan yang berhubungan dengan ekowisata untuk menjaga kelestarian alamnya dan dapat berkontribusi positif pada keberlanjutan ekonomi dengan memacu pengembangan ekonomi lokal melalui UKM yang ada (Firdaus \& Tutri, 2017; Jaafar \& Maideen, 2012) Pengembangan potensi destinasi pariwisata tentunya juga akan berdampak terhadap kondisi sosial ekonomi warga, seperti hasil penelitian Olu et al. (2018) terkait kontribusi pariwisata di Nigeria dan Etiopia (Gedecho \& Guangul, 2017).

Pariwisata yang berbasis pada pulau kecil mempunyai tantangan yang signifikan dalam pengembangan pariwisata berkelanjutan, karena memiliki sumber daya yang terbatas, kegiatan ekonomi dan sosial cenderung terkonsentrasi pada zona pesisir, dan keterkaitan antar aspek ekonomi, lingkungan, sosial-budaya dan politik sangat kuat. Akibatnya, pengembangan pariwisata berkelanjutan lebih merupakan kebutuhan praktis daripada sesuatu yang memiliki nilai tambah (Twining-Ward \& Butler, 2002). Salah satu tantangan pengembangan pariwisata di Pulau Maratua adalah ketersediaan air. Kondisi air pada destinasi pariwisata pulau kecil atau pulau karang antara lain air telah tercemar, sumur penduduk mengalami instrusi air laut, air 
sumur penduduk melampaui baku mutu air kelas I, krisis air sudah di depan mata, dan industri pariwisata mengkonsumsi air lebih banyak dari penduduk lokal (Cole \& Browne, 2015).

Pulau Maratua yang merupakan bagian dari Kawasan Segitiga Terumbu Karang Dunia (Coral Triangel) yang kaya akan keanekaragaman hayati laut. Lebih dari 1.000 species biota laut dan 832 species ikan karang serta menjadi habitat penting bagi penyu hijau (chelonia mydas) dan pari manta yang mulai langka keberadaannya. Sehingga Pulau Maratua juga merupakan Kawasan Konservasi Pesisir dan Pulau-Pulau Kecil Kepulauan Derawan dan Perairan sekitarnya di Kabupaten Berau Provinsi Kalimantan Timur, sekaligus sebagai Taman Pesisir dan Taman Pulau Kecil (Kemen KKP, 2016). Hal tersebut menyebabkan Pulau Maratua juga memerlukan pengelolaan khusus karena merupakan kawasan konservasi.

Sama halnya dengan pengelolaan pariwisata di BMT TN Kutai di Kota Bontang yang merupakan kawasan konservasi, pengelolaannya untuk keberlanjutan. Upaya-upaya yang diperlukan untuk mencapai tujuan tersebut, antara lain: pengaturan dan pengelolaan jumlah usaha pariwisata yang terdiri dari transportasi pariwisata, tour guide, mice, biro perjalanan wisata, agen perjalanan wisata; meningkatkan jumlah usaha sarana pariwisata (akomodasi, restoran/rumah makan, dan lainnya) bagi penduduk lokal; meningkatkan jumlah pelatihan pelaku ekonomi kreatif daerah berbasis IPTEK serta meningkatkan kontribusi sektor pariwisata (Setyasih et al., 2018). Meskipun demikian, untuk menjaga kelestarian dan keberlanjutan wisata alam di Kalimantan Timur, maka pengembangan dan pengelolaan destinasi wisata berbasis ecotourism dan kearifan lokal. Strategi utama yang dapat diterapkan di Pulau Maratua antara lain mempromosikan potensi yang ada, dibuat perencanaan kerja lima tahun untuk pengembangan wisata berkelanjutan, menambah obyek wisata yang menjadi icon khas, melibatkan masyarakat dalam pengelolaan wisata dan menjalin kerjasama dengan para pihak sehingga pengembangan obyek wisata dapat menjadi lebih baik. Hal tersebut juga dilakukan oleh pengelola BMT TN Kutai, sehingga tidak perlu kuatir bersaing dengan destinasi wisata lainnya karena juga memiliki potensi yang tidak kalah menarik (Setyasih et al., 2018).

\section{Kesimpulan}

Potensi obyek wisata Pulau Maratua yang bisa dikembangkan yaitu flora dan fauna hutan mangrove, panorama alam, wisata bahari, spot diving dan snorkeling, dan budaya. Pulau Maratua diharapkan menjadi salah satu destinasi pariwisata utama di kawasan Indonesia timur, sebab memiliki potensi yang besar untuk dikembangkan. Berdasarkan enam kriteria ADO-ODTWA yang digunakan untuk menganalisis potensi pariwisata Pulau Maratua, menunjukkan bahwa Pulau Maratua layak sebagai destinasi pariwisata dengan indeks $84 \%$. Hasil penilaian enam kriteria tersebut meliputi daya tarik $94 \%$, aksesibilitas $75 \%$, kondisi social ekonomi $83 \%$, akomodasi $83 \%$, sarana dan prasarana penunjang $80 \%$, dan ketersediaan air bersih $87 \%$.

Dari segi akomodasi dan fasilitas wisata serta faktor sosial budaya sudah mendukung Pulau Maratua sebagai destinasi wisata di Indonesia bagian timur. Namun demikian, masih banyak hal yang perlu dikembangkan untuk mendukung sebagai destinasi pariwisata, seperti infrastruktur, ketersediaan air bersih, dan TPA. Untuk itu diperlukan sinergi antara pemerintah, masyarakat, dan pengusaha pariwisata dalam mengembangkan potensi Pulau Maratua sebagai destinasi pariwisata di Kawasan Indonesia timur. Selain itu juga masih diperlukan terobosan untuk meningkatkan jumlah wisatawan ke Pulau Maratua.

\section{Konflik Kepentingan}

Penulis menyatakan tidak ada konflik kepentingan dalam penulisan artikel ini.

\section{Daftar Pustaka}

Badarab, F., Trihayuningtyas, E., \& M. Liga Suryadana. (2017). Strategi Pengembangan Destinasi Pariwisata di Kepulauan Togean Provinsi Sulawesi Tengah. The Journal: Tourism and Hospitality Essential Journal, 7(2), 97-112. https://doi.org/10.17509/thej.v7i2.9016 
Baskoro, J. D. (2018). Implementasi Kebijakan Pengembangan Pariwisata (Kabupaten Belitung Timur, Provinsi Kepulauan Bangka Belitung). Sekolah Tinggi Pembangunan Masyarakat Desa "APMD."

Budiani, S. R., Wahdaningrum, W., Yosky, D., Kensari, E., Pratama, H. S., Mulandari, H., ... Kusmiati, Y. (2018). Analisis Potensi dan Strategi Pengembangan Pariwisata Berkelanjutan Berbasis Komunitas di Desa Sembungan, Wonosobo, Jawa Tengah. Majalah Geografi Indonesia, 32(2), 170. https://doi.org/10.22146/mgi.32330

Cole, S., \& Browne, M. (2015). Tourism and Water Inequity in Bali: A Social-Ecological Systems Analysis. Human Ecology, 43(3), 439-450. https://doi.org/10.1007/s10745-0159739-z

Departemen Kehutanan RI. (2003). Pedoman Analisis Daerah Objek ODTWA. Bogor: Dirjen Perlindungan dan Konservasi Alam.

Firdaus, F., \& Tutri, R. (2017). Potensi Pengembangan Ekowisata Di Nagari Kotobaru, Kecamatan X Koto, Kabupaten Tanah Datar, Sumatera Barat. Jurnal Kawistara, 7(2), 115206. https://doi.org/10.22146/kawistara.13570

Gedecho, E. K., \& Guangul, A. T. (2017). Tourism potential and constraints: Considering the natural and cultural attractions of South Omo, Ethiopia. African Journal of Hospitality, Tourism and Leisure, 6(1), 0-23.

Hendriawan, N., \& Mulyanie, E. (2018). Analisis Potensi Pariwisata Air Terjun di Kabupaten Tasikmalaya. Jurnal Geografi, 15(1), 37-44.

Jaafar, M., \& Maideen, S. A. (2012). Ecotourism-related products and activities, and the economic sustainability of small and medium island chalets. Tourism Management, 33(3), 683-691. https://doi.org/10.1016/j.tourman.2011.07.011

Kemenpar. (2011). Peraturan Pemerintah Republik Indonesia Nomor 50 Tahun Indonesia 2011 Tentang Rencana Induk Pembangunan Kepariwisataan Nasional Tahun 2010 - 2025 (p. 50). p. 50. Jakarta.

KKP, K. Keputusan Menteri Kelautan dan Perikanan RI No 87/Kepmen-KP/2016 Tentang Kawasan Konservasi Pesisir dan Pulau-Pulau Kecil Kepulauan Derawan dan Perairan Sekitarnya di Kabupaten Berau Provinsi Kalimantan Timur. , (2016). Indonesia.

Kristin, R., \& Salam, R. (2016). Peran Pemerintah Daerah dalam Pengembangan Pariwisata Alam dan Budaya di Kabupaten Tapanuli Utara. Ilmu Pemerintahan Dan Sosial Politik, 4(1), 79-96.

Kumala, M., Soelistyo, A., \& Nuraini, I. (2017). Analisis potensi sektor pariwisata sebagai sektor unggulan di wilayah jawa timur. Ilmu Ekonomi, 1(4), 474-481.

Kwon, J., Chung, T., Yoon, S. H., \& Kwon, K. B. (2017). Importance and Satisfaction of Destination Attraction for Water-Based Tourism in Jeju Island. Asian Social Science, 13(10), 1. https://doi.org/10.5539/ass.v13n10p1

Martín, J. M. M., Fernández, J. A. S., Martín, J. A. R., \& de Dios Jiménez Aguilera, J. (2017). Assessment of the tourism's potential as a sustainable development instrument in terms of annual stability: Application to Spanish rural destinations in process of consolidation. Sustainability (Switzerland), 9(10). https://doi.org/10.3390/su9101692

Middleton, V. (2001). Marketing In Travel And Tourism;A Division Of Reed Educational And Profesional. UK: Publishing.Ltd: Oxford.

Nugroho, K. (2018). Implementasi Pengembangan Pariwisata Di Pantai Kelapa Kelurahan Panyuran Kecamatan Palang Kabupaten Tuban. DIA: Jurnal Ilmiah Administrasi Publik, 16(1), 39. https://doi.org/10.30996/dia.v16i1.1914

Olu, A. J., Ben, O. O., \& Paul, O. T. (2018). Assessment of Tourism Potentials and Their Contributions to The Socio-Economic Development of Idanre People , Ondo State , Nigeria. World Journal of Research and Review, 6(4), 52-58.

Pemkab Berau. (2018). Pariwisata Kabupaten Berau. Pemerintah Kabupaten Berau.

Setiawan, N. (2007). Penentuan Ukuran Sampel Memakai Rumus Slovin dan Tabel KrejcieMorgan: Telaah Konsep dan Aplikasinya. Diskusi Ilmiah Jurusan Sosial Ekonomi Fakultas Peternakan UNPAD, (November), 1-10.

Setyasih, I., Anwar, Y., \& Anikmahardi, I. (2018). Strategi Pengembangan Wisata Bontang Mangrove Park Taman Nasional Kutai Di Kalimantan Timur. Pertemuan Ilmiah Tahunan (PIT) XX Ikatan Geograf Indonesia (IGI), 783-795. Manado: Jurusan Pendidikan Geografi, 
FIS Unima.

Sidqi, M., Suharyanto, S., Astuti, R. Y., \& Ardarini, F. (2019). Analisis Kesesuaian Rencana Zonasi Kawasan Strategis Nasional Tertentu Terhadap Pemanfaatan Ruang Laut Eksisting Sektor Wisata Bahari Di Pulau Kecil Terluar (Studi Kasus di Pulau Maratua, Kabupaten Berau). Seminar Nasional Geomatika, 3, 957. https://doi.org/10.24895/sng.2018.3-0.1062

Sugiyono. (2004). Metode Penelitian. Bandung: Alfabeta.

Susmoro, H. (2019). Penamaan Laut dan Samudera: Tata Cara dan Implementasinya (Dyan Primana, Ed.). Jakarta: Pusat Hidrografi dan Oseanografi TNI AL.

Sutamihardja. (2004). Perubahan Lingkungan Global. Bogor: Program Studi Pengelolaan Sumber Daya Alam dan Lingkungan Sekolah Pascasarjana IPB.

Suwantoro, G. (2004). Dasar-Dasar Pariwisata. Yogyakarta: Andi.

Twining-Ward, L., \& Butler, R. (2002). Implementing std on a small island: Development and use of sustainable tourism development indicators in samoa. Journal of Sustainable Tourism, 10(5), 363-387. https://doi.org/10.1080/09669580208667174

Yoeti, O. A. (2002). Perencanaan Strategis pemasaran daerah tujuan wisata. Jakarta: Pradnya Paramita. 